\title{
Identifying Key Challenges of the National Energy and Climate Plan through Climate Policy Integration Approach
}

\author{
Reinis ABOLTINS ${ }^{1 *}$, Dzintars JAUNZEMS ${ }^{2}$ \\ ${ }^{1,2}$ Institute of Energy Systems and Environment, Riga Technical University, Āzenes iela 12/1, Riga, \\ LV-1048, Latvia
}

\begin{abstract}
The purpose of the study was to analyse to what extent Latvia's National Energy and Climate Plan 2030 (NECP2030) is in synergy with climate policies formulated in other strategic and policy documents through applying Climate Policy Integration approach (CPI). $\mathrm{CPI}$ is defined as integration of activities aimed at mitigating climate change as well as adaptation activities in all policy making levels and stages in other policy sectors and commitment to reduce and prevent contradictions between climate policy and goals and policies and goals of other sectors. NECP2030 is intended to be the manual of policies and policy instruments aimed at achieving changes in production and use of energy resources and energy that result in sustainable economic policy, which functions in line with climate goals. NECP2030 has 12 activity groups covering a spectrum of policy measures. The study concludes that there are policies, which do not function in synergy with climate policy or are even of competitive nature vis-à-vis climate policy.
\end{abstract}

Keywords - Climate policy integration; energy and climate plan; energy policy; policy instruments

\section{INTRODUCTION}

Climate policy has returned to the core of EU policies and functions as the point of reference for many policy sectors. It can be argued that climate policy is experiencing a significant boost through its central placing in EU energy and climate policy. The European Green Deal serves as a beacon for the transition to net-zero emission economy with carbon reduction at the centre of all policies, but especially those, which contribute most of carbon emissions energy production, transport, and agriculture [1]. Transformation of such a vast scale is supported by industry, which has embraced the changes [2]. The situation can be explained by readiness of policy makers, innovators, energy producers, and energy consumers to embrace the next logical stage in sociotechnical transition. However, this can only take place with a sound policy making in place [3], which requires synergetic interaction of sectoral policies with climate policy. Ideally, climate policy goals should be integrated in sectoral policies and should have priority status vis-à-vis sectoral policy goals [4], [5]. In other words, when defining goals of sectoral policies, aspects related to achieving climate goals must serve as the point of departure. Lack of synergy may jeopardise reaching the desired climate policy goals in an optimal way or even be contrary to climate goals through competing or even mutually excluding definitions and goals [6].

* Corresponding author.

E-mail address: reinis.aboltins@live.com 
One of the key assumptions of preparing a national energy and climate plan according to a uniform approach defined by the EU policies is that the implementation of NECP policies will ensure progress towards climate neutrality [7]. NECP should serve as the policy document prioritising climate policy goals over policy goals of other sectors of economy [8], [9]. However, analysis of Latvia's National energy and climate plan (NECP2030) by applying Climate Policy Integration (CPI) approach shows that such an assumption may not reflect the reality.

In an effort to highlight shortcomings in reconciling national climate and other policy areas, this study reviews policies identified as the so-called horizontal activities of the NECP2030 representing policies and policy measures that ought to play critical role in achieving climate goals. The study aspires to identify whether contradictions and competing interests stem from the way policy goals and measures are defined in the NECP2030 with the ultimate goal of improving future iterations of the relevant policy document. Introduction of the study is followed by description of methodology, which highlights the logic behind applying a combination of hugs, carrots and sticks approach and Climate Policy Integration approach to analyse the interaction of climate policy goals and policies defined as horizontal in Latvia's NECP2030. The Results section illustrates the assessment of policies and policy measures from the CPI perspective, followed by discussion and conclusions.

\section{METHODOLOGY}

There are 13 groups of policy measures (activity directions) in NECP2030. A separate group of policy measures encompasses what is defined as horizontal activities having crosssectoral impact. 12 groups represent sector-specific policy measures. The study aims to determine whether policies represented in the horizontal group of activities of the NECP2030 are in line with climate goals and to what extent they can contribute to reaching climate goals.

The study

1. Identifies, which strategic documents define climate policy and goals;

2. Identifies, which type each activity represents according to hugs, carrots and sticks approach;

3. Assesses the horizontal policies / policy instruments of Latvia's NECP2030 according to the Climate Policy Integration approach;

4. Draws conclusions about interaction of NECP2030 horizontal policies and climate goals (see Fig. 1).

\subsection{Latvia's Climate Policy and Goals}

Latvia's climate policy and goals are defined in the following strategies and policy documents: Plan for the adaptation to climate change for the period till 2030 (2019), Strategy for reaching climate neutrality till 2050 (2019) and National Energy and Climate Plan 2030 (2020).

\subsubsection{Plan for the Adaptation to Climate Change for the Period till 2030 (PACC2030)}

Although defining climate policy and goals is not the primary task of the PACC2030 it includes a direct reference to the importance of climate goals for the overall economy saying that 'the Strategy is a long-term strategic document, which must be implemented by horizontally integrating GHG and climate resilience goals in all sectors of economy'. The overall goal of the PACC2030 is to achieve climate neutrality by 2050 including by implementing policies, which limit or mitigate climate change. 
PACC2030 is centred around four elements - people, economy, infrastructure, and nature. They provide a framework for the implementation of the PACC2030 in two main policy directions: 1) mitigation of the negative consequences, risks and vulnerabilities associated with climate change, and 2) utilisation of opportunities created by climate change [10].

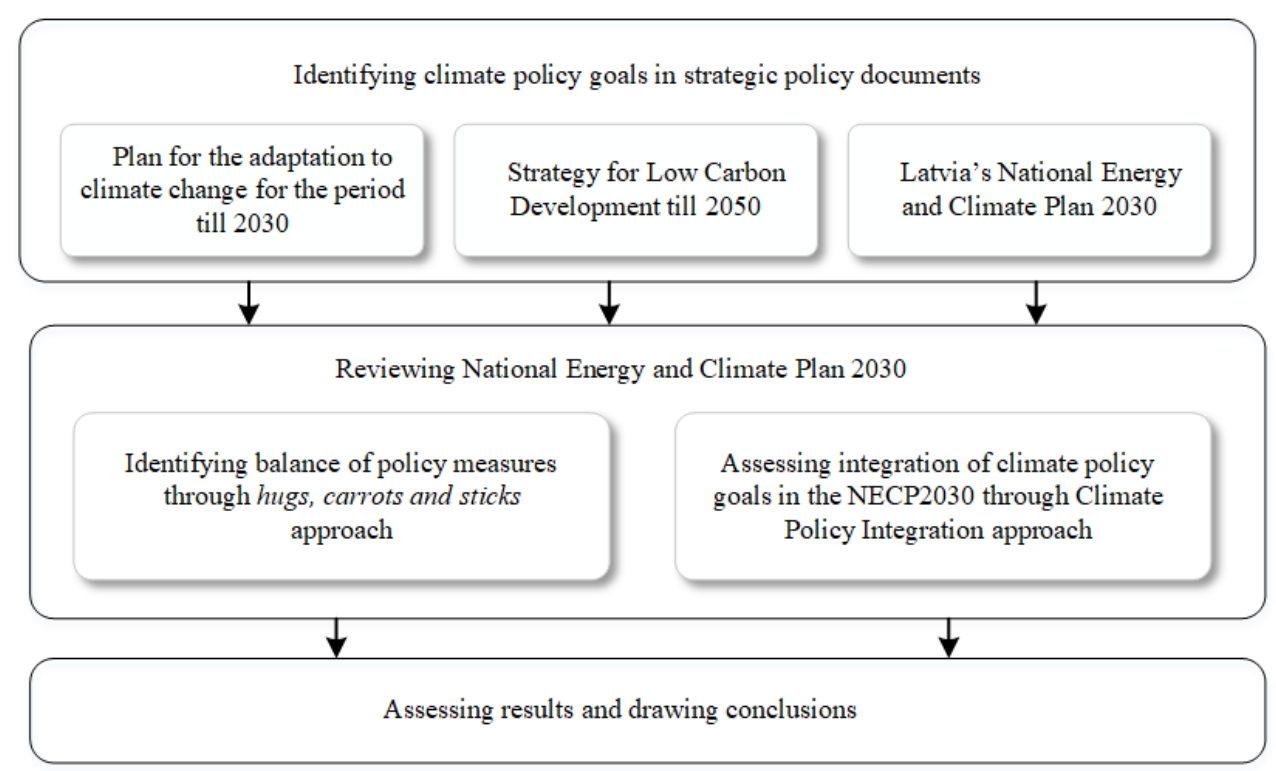

Fig. 1. Algorithm of the study.

\subsubsection{Strategy for Low Carbon Development till 2050}

The Strategy for Low Carbon Development till 2050 (LCD2050), also known as the Strategy for Achieving Climate Neutrality till 2050, is a long-term policy planning document elaborated with the aim of limiting and mitigating climate change while facilitating economic development and competitiveness, as well as ensuring a safe environment for living. The LCD2050 was developed according to the commitments stemming from the Paris Agreement [11] and the EU Regulation on the Governance of the Energy Union and Climate Action [12]. The LCD2050 has two strategic goals: 1) GHG reduction in all sectors of the economy and 2) increase of $\mathrm{CO}_{2}$ sequestration. Progress towards climate neutrality is measured by using indicators related to changes in GHG emission intensity and volume in all sectors of economy including land use, land use change and forestry [13].

\subsubsection{Latvia's National Energy and Climate Plan 2030 (NECP2030)}

NECP2030 is a long-term energy and climate policy planning document defining the basic principles, goals, and policy directions for the period till 2030 while keeping in mind the long-term development strategy till 2050. NECP2030 identifies quantitative indicators for the European Energy Union policy dimensions comparing the indicator values in 2020 with the expected target values in 2030. The long-term goal of the NECP2030 is to facilitate development of climate neutral economy while ensuring ever improving energy security and social welfare in a sustainable, competitive and cost-efficient and market-based manner. Efficient use of resources, significant reduction of use of fossil fuels and transition to renewable energy through innovative solutions are identified as some of the key principles of 
the Plan aimed at facilitating sustainable development of the energy sector and climate change mitigation. Annex 4 of the NECP2030 lists a separate group of horizontal policies (activities) that should be implemented across all sectors of economy [14].

\subsection{Hugs, Carrots and Sticks Approach}

Implementation of NECP2030 policies and policy instruments (activities) is supposed to ensure progress towards achieving climate goals. The right balance between different types of policy instruments can be a challenging task. This study applies the filter of hugs, carrots and sticks (HCS) approach to identify, which type of policy measure each of the NECP2030 horizontal activities (policy instruments) represents. The purpose of hugs is to achieve a consensus through convincing, educating and participation. Carrots reward and compensate for the desired action. Sticks allow achieving the desired effect through applying mandatory methods, threats or punishment [15].

The HCS approach is associated with the work of Kenneth Boulding and it has been used widely to analyse, formulate and apply different policy instruments with the aim of achieving the desired economic behaviour through using information and education, reward or imposition to mobilise individuals for action [16] and employing learning as an essential tool for achieving behavioural change [17]. It is argued that a correct balance of persuasion [18], coercion [19], possibility to avoid loss [20] and benevolent motivating measures [21] is essential to stimulate rational behaviour [22].

\subsection{Climate Policy Integration (CPI) approach}

Historically attempts to integrate environmental and climate issues into policies aimed at sustainable development can be referenced back to 1992 when the UN Committee on Environment and Development adopted Agenda 21 representing a plan of action to be taken globally, nationally and locally in every area in which there is a human impact on the environment [23]. Policy planning should pursue the principle of climate policy integration [24]. Climate policy should not be viewed detached from policies of many sectors of the economy. Climate policy rather has to be looked at as a horizontal policy element represented in every sectoral policy [25]. Integration of climate policy in sectoral policies prevents climate and environmental issues from being neglected and sectoral policies potentially coming into conflict with climate policy goals. Jordan and Kivimaa argue that horizontal integration of climate policy works better than attempts to pursue the path of vertical control over the implementation of climate policy aspects in sectoral policies [25], [26]. Environmental Policy Integration (EPI) was the approach describing integration of environmental policy aspects into other policy areas prior to Climate Policy Integration (CPI). Interestingly, when debating indicators for measuring EPI Lafferty and Hovden distinguish between group of vertical and horizontal indicators, the former applying to how government sectors implemented EPI and the latter focusing on the ability of centrally administering integration of environmental policy aspects in sectoral policies and arguing that the vertical dimension of policy integration matters more and can achieve more as centralised attempts to dispatch environmental policy aspects across sectors might produce a broad spectrum of results depending on factors like the competence and place in the governance hierarchy of a particular administrative unit, or instruments chosen to implement environmental aspects of a policy [27]. Integration of climate issues in other sectors' policies relates to the output aspects of climate policy integration while the involvement of stakeholders from across the entire spectrum of sectors of the economy and recognition of 
interrelation of policies with climate policy goals pertains to the policy process aspects of CPI [28], [29].

Sectoral policies are defined in strategic development and policy planning documents, which is the first step towards recognising the importance of climate goals or, vice versa lack of climate policy aspects in policy documents is indicative of potential problems to achieve climate goals. Analysis of sectoral policies (be it ex-ante assessment or periodic policy review) must assess whether a policy contains climate policy aspects - what policy goals are set, do they respect climate aspects, do specific policies and policy instruments foresee adherence to climate goals, and, if included, whether the principles of sound climate policy are actually implemented [30].

Climate policy integration is defined as integration of activities aimed at mitigating climate change as well as adaptation activities in all policy making levels and stages in other policy sectors supplemented by inclusion of impact assessment of climate change mitigation and adaptation policies in the overall policy assessment, and commitment to reduce and prevent contradictions between climate policy and goals and policies and goals of other sectors. According to this definition climate policy goals are ascribed higher priority in sectors that are not related to environmental policies. Climate policy integration should be reflected in overall strategic policy objectives as well as specific sectoral strategic and policy planning documents as well as among the defined policy outcomes and GHG emission reduction [31].

Climate policy integration as an approach to policy planning has experienced strong interest and application. EU energy and climate policy is an example of this trend represented, for example, by Europe 2020 Strategy where climate change and energy is one of five main directions of action [32]. Climate policy integration into other policy areas and synergy of policies with climate policy is critical for achieving optimal implementation and impact of policies on climate goals. Lack of synergy or competing interests prevent from achieving optimal implementation and impact (creating a situation of suboptimal solution), which has negative impact on reaching long-term and strategic goals of policies [24].

Policy assessment by applying Climate Policy Integration approach addresses four key questions [28]:

1. Do sectors have functional relationship and what kind relationship it is - is there a direct or indirect relationship and do policies conflict with each other or function in synergy?

2. Does political commitment to define climate policy goals exist in key strategic development documents and in specific sectoral policies?

3. Is there political commitment to reflect climate policy integration in the institutional and policy context?

4. Does climate policy integration have impact on policy outcomes?

This analysis assesses interaction between NECP2030 policies and climate policy setting climate policy goals and tasks defined in Latvia's climate policy documents as the point of reference. Table 1 represents the logical scheme of factors and criteria according to which impact of policy $\mathrm{X}$ on climate policy (defined in other policy documents) is assessed. Following factors are used: political commitment, functional overlap, policy instruments, weight, time perspective, and cost of GHG reduction. The latter factor has been added to the original scheme with the purpose of assessing the impact on the prospects of achieving climate goals of such an important factor as levelized cost of energy (LCOE) if and when applicable for the purpose of analysis. The identified factors are analysed by using following criteria: Is a factor neutral? Does policy X create synergy with climate goals? Are policy goals defined clearly in a policy? Does policy X conflict with climate policy? The assessment of interaction of climate policy with policy $\mathrm{X}$ has been expressed as follows: $\mathrm{A} 1=0$ or 1 , where 0 indicates that the respective factor does not correspond the criterion and 1 indicates 
the respective factor corresponds the criterion. Further, simple markers have been introduced to the original table by Kettner and Kletzan-Slamanig to visualise presence of factors indicative of potentially conflicting situations between energy policy and climate policy according to the Clarity of interaction and Conflict with other policies criteria. These are used in Section 3 (Results) to highlight problem areas among the horizontal policies represented in the NECP2030.

TABle 1. Interaction of Policy / Policy Instrument With Climate Policy (AdAPTED FROM KETTNER AND KLETZAN-SLAMANIG 2020)

\begin{tabular}{|c|c|c|c|c|}
\hline \multicolumn{5}{|c|}{ Policy / Policy instrument } \\
\hline Factor & $\begin{array}{l}\text { Neutral interaction } \\
1\end{array}$ & $\begin{array}{l}\text { Synergetic } \\
\text { interaction } \\
2\end{array}$ & $\begin{array}{l}\text { Clarity of interaction } \\
3\end{array}$ & $\begin{array}{l}\text { Conflict with other } \\
\text { policies } \\
4\end{array}$ \\
\hline $\begin{array}{l}\text { Political } \\
\text { commitment } \\
\text { (A) }\end{array}$ & $\begin{array}{l}\text { [A1] Commitment to } \\
\text { achieve climate goals is } \\
\text { formulated as } \\
\text { motivation (no other } \\
\text { conflicting goals) }\end{array}$ & $\begin{array}{l}\text { [A2] Commitment to } \\
\text { achieve climate goals } \\
\text { is formulated as the } \\
\text { main motivation (no } \\
\text { other conflicting } \\
\text { goals) }\end{array}$ & $\begin{array}{l}\text { [A3] Climate goal } \\
\text { commitment exists } \\
\text { along with } \\
\text { conflicting goals of } \\
\text { other policies }\end{array}$ & $\begin{array}{l}\text { [A4] No specific } \\
\text { climate goal } \\
\text { commitment and } \\
\text { existing commitments } \\
\text { conflict with goals of } \\
\text { other policies }\end{array}$ \\
\hline $\begin{array}{l}\text { Functional } \\
\text { overlap } \\
\text { (B) }\end{array}$ & $\begin{array}{l}\text { [B1] No overlap } \\
\text { between policy goals }\end{array}$ & $\begin{array}{l}\text { [B2] Policy goals } \\
\text { facilitate or } \\
\text { strengthen climate } \\
\text { policy }\end{array}$ & $\begin{array}{l}\text { [B3] Policy goals are } \\
\text { in partial synergy and } \\
\text { partial conflict with } \\
\text { climate policy }\end{array}$ & $\begin{array}{l}\text { [B4] Policy goals } \\
\text { obstruct or work } \\
\text { against climate goals }\end{array}$ \\
\hline $\begin{array}{l}\text { Policy } \\
\text { instruments } \\
\text { (C) }\end{array}$ & $\begin{array}{l}\text { [C1] Policy instruments } \\
\text { do not influence GHG } \\
\text { emissions }\end{array}$ & $\begin{array}{l}\text { [C2] Policy } \\
\text { instruments facilitate } \\
\text { reduction of GHG } \\
\text { emissions }\end{array}$ & $\begin{array}{l}\text { [C3] Policy } \\
\text { instruments facilitate } \\
\text { both GHG increase } \\
\text { and reduction }\end{array}$ & $\begin{array}{l}\text { [C4] Policy instruments } \\
\text { (potentially) increase } \\
\text { GHG emissions }\end{array}$ \\
\hline $\begin{array}{l}\text { Weight } \\
\text { (D) }\end{array}$ & $\begin{array}{l}\text { [D1] No correlation } \\
\text { between policy goals }\end{array}$ & $\begin{array}{l}\text { [D2] Climate goals } \\
\text { have higher priority } \\
\text { as a matter of } \\
\text { principle }\end{array}$ & $\begin{array}{l}\text { [D3] Climate goals } \\
\text { have higher priority } \\
\text { under certain } \\
\text { conditions }\end{array}$ & $\begin{array}{l}\text { [D4] Other policies } \\
\text { have priority over } \\
\text { climate policy }\end{array}$ \\
\hline $\begin{array}{l}\text { Time perspective } \\
\text { (E) }\end{array}$ & [E1] NA & $\begin{array}{l}\text { [E2] Policy reflects } \\
\text { long-term climate } \\
\text { policy goals }\end{array}$ & $\begin{array}{l}{[\text { E3] Policy includes }} \\
\text { medium-term climate } \\
\text { goals }\end{array}$ & $\begin{array}{l}\text { [E4] Short-term } \\
\text { policymaking }\end{array}$ \\
\hline $\begin{array}{l}\text { Cost of GHG } \\
\text { reduction } \\
\text { (F) }\end{array}$ & $\begin{array}{l}\text { [F1] Policy financing is } \\
\text { not related to financing } \\
\text { for other solutions }\end{array}$ & $\begin{array}{l}{[\mathrm{F} 2] \text { Policy has }} \\
\text { positive interaction } \\
\text { with other solutions }\end{array}$ & $\begin{array}{l}{[\mathrm{F} 3] \text { Policy both }} \\
\text { positively interacts } \\
\text { and conflicts other } \\
\text { solutions }\end{array}$ & $\begin{array}{l}{[\mathrm{F} 4] \text { Policy is in }} \\
\text { conflict with other } \\
\text { solutions in other } \\
\text { sectors }\end{array}$ \\
\hline
\end{tabular}

To analyse connection / synergy between climate policy goals and policy goals of sectors of economy both climate policy goals (including [quantitative] indicators) and sectoral policy goals and instruments to be used to achieve goals should be defined. If it is assumed that an optimal way how to include climate policies in energy or other sectoral policies to reach climate goals in the best possible way exists, then any other solution that is not optimal will not allow also reaching climate goals. For example, energy policy is influenced by four important goals (and they have impact on GDP, GHG and $\mathrm{CO}_{2}$ ):

1. Secure, sufficient and diversified availability of primary resources;

2. Reliable and stable infrastructure for energy transformation and supply (transmission and distribution);

3. Stable energy supply for affordable price;

4. Environmentally friendly energy production and consumption. 


\section{Results}

\subsection{NECP2030 Horizontal Policies According to the Hugs, Carrots and Sticks Approach}

The horizontal policies have been reviewed by applying Climate Policy Integration approach to assess to what extent they are in line with climate policy goals and whether they can strengthen progress towards climate policy goals through the implementation of NECP2030 policies. NECP2030 says that the cluster of horizontal policies has been created with the purpose of putting together policies, whose activities and impact reaches beyond one separate activity direction [of the NECP2030]. Two conclusions stem from such an approach: 1) horizontal policies have the biggest potential to influence positively several policy directions in different sectors of the economy simultaneously, and 2) the cluster of horizontal policies would potentially have bigger impact on reaching climate goals if policies (activities) would have been included in this activity group more purposefully - with the focus on achieving strongest possible positive impact on climate goals.

Reference to the assessment of NECP2030 according to the hugs, carrots and sticks approach is made in this assessment (see Table 2). Such an approach allows for a more effective assessment of interaction of NECP2030 policies with climate policy considering the type of policy instrument (hugs, carrots, or sticks) employed: impact of and role in interaction of one stick type policy instrument can be significantly bigger than several hugs and carrots. Also, information about the type of NECP2030 policy instrument allows for a more effective assessment of interaction of policies with climate policy forecasting whether interaction is going to be synergetic, mutually competitive, or even mutually excluding.

TABle 2. Horizontal ACTIVITy Directions (EQUALLING 14 ACTIVITY GROUPS) OF THE NECP2030 ACCORDING TO HUGS, CARROTS AND STICKS APPROACH

\begin{tabular}{|c|c|c|c|}
\hline & Activities (by type) & & \\
\hline Policy direction & $\begin{array}{l}\text { Total Hugs } \\
\text { number of } \\
\text { activities }\end{array}$ & Carrots & Sticks \\
\hline
\end{tabular}

\begin{tabular}{|c|c|c|c|c|}
\hline Horizontal activities & 44 & 36 & 8 & 17 \\
\hline H1 Application of 'energy efficiency first' principle & 3 & 1 & 0 & 2 \\
\hline $\begin{array}{l}\text { H2 Expanding EPS to significantly facilitate implementation of } \\
\text { energy efficiency measures by big energy suppliers and energy } \\
\text { consumers }\end{array}$ & 2 & 2 & 0 & 2 \\
\hline
\end{tabular}

\begin{tabular}{lccc}
\hline $\begin{array}{l}\text { H3 Strengthening of agreements about improving energy } \\
\text { efficiency measures, use of RES and energy efficiency services } \\
\text { with simultaneous support to contracting and implementation }\end{array}$ & 3 & 1 & 2 \\
\hline $\begin{array}{l}\text { H4 Improving the system of monitoring energy saving, and } \\
\text { reporting about implemented activities }\end{array}$ & 3 & 1 & 0 \\
\hline H5 Facilitating production and use of biogas and biomethane & 3 & 0 & 0 \\
\hline $\begin{array}{l}\text { H6 Ensuring full-fledged functioning of the system of } \\
\text { certificates of origin }\end{array}$ & 5 & 4 & 0 \\
\hline
\end{tabular}




\begin{tabular}{|c|c|c|c|c|}
\hline $\begin{array}{l}\text { H7 Simplifying and speeding up the procedure (including } \\
\text { permits) of introduction of RES technologies and ensuring } \\
\text { public benefit from RES projects }\end{array}$ & 5 & 5 & 0 & 0 \\
\hline $\begin{array}{l}\text { H8 Facilitating acquisition of financing for stimulating use of } \\
\text { RES and energy efficiency }\end{array}$ & 8 & 8 & 6 & 0 \\
\hline $\begin{array}{l}\text { H9 Evaluating possibility to introduce trading of energy } \\
\text { savings }\end{array}$ & 1 & 1 & 1 & 0 \\
\hline $\begin{array}{l}\text { H10 Carrying out research about availability of RES for energy } \\
\text { production (except for wind energy) in Latvia's territorial } \\
\text { waters, including evaluation of possibility of building new } \\
\text { infrastructure }\end{array}$ & 3 & 3 & 0 & 0 \\
\hline H11 Expanding the work of Energy and climate council & 2 & 2 & 0 & 0 \\
\hline $\begin{array}{l}\text { H12 Introducing and applying social conditions aspect in } \\
\text { energy and climate policy }\end{array}$ & 2 & 2 & 0 & 2 \\
\hline $\begin{array}{l}\text { H13 Elaborating solution for the number of parallel } \\
\text { connections of energy supply systems }\end{array}$ & 1 & 1 & 0 & 0 \\
\hline $\begin{array}{l}\text { H14 Elaborating research programmes to stimulate research on } \\
\text { reaching energy and climate goals }\end{array}$ & 3 & 3 & 0 & 0 \\
\hline
\end{tabular}

There are three key challenges to achieving climate policy goals:

1. Ensure that the strongest possible impact from policy implementation can be achieved by applying policy instruments where hugs dominate;

2. Ensure that climate goals enshrined in sectoral policies have priority over other defined goals;

3. Ensure that climate goals included in various strategic and policy planning documents are defined in synergetic rather than mutually competitive way.

Analysis of the EU renewable energy and energy efficiency legislation highlights these two areas as an example where climate policy integration into documents regulating development of the energy sector facilitates and strengthens progress towards achieving climate and GHG emission reduction goals [4].

\subsection{Analysis of Horizontal Policy Directions through Climate Policy Integration Approach}

Further the horizontal policies (H1 to H14) of the NECP2030 are assessed to determine if these policies and policy instruments are in line with and can contribute to climate policy goals defined in the relevant strategic and policy planning documents identified in section 2.2.

\subsubsection{H1 - Application of 'Energy Efficiency First' Principle}

Energy efficiency policy and activities implemented under the policy facilitate reduction of GHG emissions - buildings consume less energy, less energy (primarily - heat) has to be supplied and produced, and less primary energy resources have to be consumed to produce energy. Energy efficiency is directed at implementing activities that produces immediate results but also fosters reaching medium and long-term GHG reduction targets. Table 3 provides assessment of policies according to the CPI framework presented in Table 1. 
TABle 3. APPLICATION OF'ENERGy EFFICIENCY FIRST' PRINCIPLE.

\begin{tabular}{|c|c|c|c|c|}
\hline Criterion & $\begin{array}{l}\text { Neutral } \\
\text { interaction } \\
1\end{array}$ & $\begin{array}{l}\text { Synergetic } \\
\text { interaction } \\
2\end{array}$ & $\begin{array}{l}\text { Clarity of } \\
\text { interaction } \\
3\end{array}$ & $\begin{array}{l}\text { Conflict with other } \\
\text { policies } \\
4\end{array}$ \\
\hline Political commitment (A) & 0 & 1 & 1 & 0 \\
\hline Functional overlap (B) & 0 & 1 & 1 & 0 \\
\hline Policy instruments (C) & 0 & 1 & 1 & 0 \\
\hline Weight (D) & 0 & 1 & 0 & 0 \\
\hline Time perspective (E) & NA & 1 & 1 & 0 \\
\hline Cost of GHG reduction $(\mathrm{F})$ & 0 & 1 & 0 & 0 \\
\hline
\end{tabular}

3.2.2. H2 - Expanding EOS to Significantly Facilitate Implementation of Energy Efficiency Measures by Big Energy Suppliers and Energy Consumers

Energy efficiency obligation schemes as a bundle of energy efficiency instruments provide direct and indirect contribution to GHG emission reduction depending on policy instrument. For example, broadening EOS to include activities, which 'improves energy efficiency and gains energy savings in end users' buildings, devices and transport, and must implement certain activities to assist consumers that are under energy poverty risk', produces a direct contribution to GHG reduction. At the same time, payments to the energy efficiency fund by the responsible parties provide an indirect contribution to energy efficiency. Table 4 provides assessment of policies according to the CPI framework presented in Table 1.

TABLE 4. EXPANDING EOS TO SIGNIFICANTLY FACILITATE IMPLEMENTATION OF ENERGY EFFICIENCY MEASURES BY BIG ENERGY SUPPLIERS AND ENERGY CONSUMERS

\begin{tabular}{lllll}
\hline Criterion & $\begin{array}{l}\text { Neutral } \\
\text { interaction } \\
\text { Factor }\end{array}$ & $\begin{array}{l}\text { Synergetic } \\
\text { interaction }\end{array}$ & $\begin{array}{l}\text { Clarity of } \\
\text { interaction } \\
3\end{array}$ & $\begin{array}{l}\text { Conflict with other } \\
\text { policies } \\
4\end{array}$ \\
\hline Political commitment (A) & 0 & 1 & 0 & 0 \\
Functional overlap (B) & 0 & 1 & 0 & 0 \\
Policy instruments (C) & 0 & 1 & 0 & 0 \\
Weight (D) & 0 & 1 & 0 & 0 \\
Time perspective (E) & NA & 1 & 1 & 0 \\
Cost of GHG reduction (F) & 0 & 1 & 1 & 0 \\
\hline
\end{tabular}

3.2.3. H3 - Strengthening of Agreements about Improving Energy Efficiency Measures, Use of RES and Energy Efficiency Services with Simultaneous Support to Contracting and Implementation

It can be forecasted that agreement about improving energy efficiency measures and other policy instruments included in the horizontal group of activities of the NECP2030 are going to work in synergy with other policy goals and will ensure progress towards achieving climate goals in medium and long-term. Table 5 provides assessment of policies according to the CPI framework presented in Table 1 . 
TABLE 5. STRENGTHENING OF AGREEMENTS ABOUT IMPROVING ENERGY EFFICIENCY MEASURES, USE OF RES AND ENERGY EFFICIENCY SERVICES WITH SiMUltaNEOUS SUPPORT TO CONTRACTING AND IMPLEMENTATION

\begin{tabular}{|c|c|c|c|c|}
\hline Criterion & $\begin{array}{l}\text { Neutral } \\
\text { interaction } \\
1\end{array}$ & $\begin{array}{l}\text { Synergetic } \\
\text { interaction } \\
2\end{array}$ & $\begin{array}{l}\text { Clarity of } \\
\text { interaction } \\
3\end{array}$ & $\begin{array}{l}\text { Conflict with other } \\
\text { policies } \\
4\end{array}$ \\
\hline Political commitment (A) & 0 & 1 & 0 & 0 \\
\hline Functional overlap (B) & 0 & 1 & 0 & 0 \\
\hline Policy instruments (C) & 0 & 1 & 0 & 0 \\
\hline Weight (D) & 0 & 0 & 1 & 0 \\
\hline Time perspective (E) & NA & 1 & 1 & 0 \\
\hline Cost of GHG reduction $(\mathrm{F})$ & 0 & 1 & 0 & 0 \\
\hline
\end{tabular}

3.2.4. H4 - Improving the System of Monitoring Energy Saving, and Reporting About Implemented Activities

Possibility to measure progress in achieving energy efficiency goals is critical for the ability to trace the dynamic of energy efficiency changes and assessment of effectiveness of policy instruments. Monitoring and reporting system makes it possible to estimate the required corrections in choosing and implementing policies in medium and long-term. Table 6 provides assessment of policies according to the CPI framework presented in Table 1.

\section{TABLE 6. IMPROVING THE SySTEM OF MONITORING ENERGy SAVING, AND REPORTING ABOUT IMPLEMENTED ACTIVITIES}

\begin{tabular}{|c|c|c|c|c|}
\hline Criterion & $\begin{array}{l}\text { Neutral } \\
\text { interaction } \\
1\end{array}$ & $\begin{array}{l}\text { Synergetic } \\
\text { interaction } \\
2\end{array}$ & $\begin{array}{l}\text { Clarity of } \\
\text { interaction } \\
3\end{array}$ & $\begin{array}{l}\text { Conflict with other } \\
\text { policies } \\
4\end{array}$ \\
\hline Political commitment (A) & 1 & 0 & 0 & 0 \\
\hline Functional overlap (B) & 0 & 1 & 0 & 0 \\
\hline Policy instruments (C) & 0 & 1 & 0 & 0 \\
\hline Weight (D) & 0 & 1 & 0 & 0 \\
\hline Time perspective (E) & NA & 1 & 1 & 0 \\
\hline Cost of GHG reduction $(\mathrm{F})$ & 0 & 1 & 1 & 0 \\
\hline
\end{tabular}

H5 - Facilitating Production and Use of Biogas and Biomethane

Use of biomethane as an alternative fuel to natural gas facilitates progress towards reaching climate goals and reduces the need to import primary energy resources. At the same time production of biomethane can potentially have negative effect on reaching climate and environmental goals: for example, there is a risk of spreading agricultural monocultures. Creating infrastructure for the use of biomethane in transport or in stationary combustion devices has the potential to reduce the use of other types of fossil fuels in transport and energy production sectors that have more negative impact on environment. Table 7 provides assessment of policies according to the CPI framework presented in Table 1. 
TABle 7. Facilitating Production and Use of Biogas and Biomethane

\begin{tabular}{|c|c|c|c|c|}
\hline Criterion & $\begin{array}{l}\text { Neutral } \\
\text { interaction } \\
1\end{array}$ & $\begin{array}{l}\text { Synergetic } \\
\text { interaction } \\
2\end{array}$ & $\begin{array}{l}\text { Clarity of } \\
\text { interaction } \\
3\end{array}$ & $\begin{array}{l}\text { Conflict with other } \\
\text { policies } \\
4\end{array}$ \\
\hline Political commitment (A) & 1 & 1 & 1 & 0 \\
\hline Functional overlap (B) & 0 & 1 & 1 & 0 \\
\hline Policy instruments (C) & 0 & 1 & 1 & 0 \\
\hline Weight (D) & 0 & 1 & 0 & 0 \\
\hline Time perspective (E) & NA & 1 & 1 & 0 \\
\hline Cost of GHG reduction $(\mathrm{F})$ & 0 & 1 & 1 & 1 \\
\hline
\end{tabular}

\subsubsection{H6 - Ensuring Full-Fledged Functioning of the System of Certificates of Origin}

Although the system of certificates of origin $(\mathrm{CoO})$ may not have a direct and immediate impact on $\mathrm{GHG}$ reduction, $\mathrm{CoO}$ as a long-term policy stimulates the role of energy origin in the energy system by using renewable energy in production and consumption of electricity and heat (from biogas) and also transport fuel (biogas / CNG). Table 8 provides assessment of policies according to the CPI framework presented in Table 1.

TABLE 8. ENSURING Full-FledGed FunCtioning OF THE SySTEM OF CERTIFICATES OF ORIGIN

\begin{tabular}{|c|c|c|c|c|}
\hline Criterion & $\begin{array}{l}\text { Neutral } \\
\text { interaction }\end{array}$ & $\begin{array}{l}\text { Synergetic } \\
\text { interaction } \\
2\end{array}$ & $\begin{array}{l}\text { Clarity of } \\
\text { interaction } \\
3\end{array}$ & $\begin{array}{l}\text { Conflict with other } \\
\text { policies }\end{array}$ \\
\hline Political commitment (A) & 0 & 1 & 1 & 0 \\
\hline Functional overlap (B) & 0 & 1 & 0 & 0 \\
\hline Policy instruments (C) & 0 & 1 & 0 & 0 \\
\hline Weight (D) & 0 & 1 & 0 & 0 \\
\hline Time perspective (E) & NA & 1 & 0 & 0 \\
\hline Cost of GHG reduction $(\mathrm{F})$ & 0 & 1 & 1 & 0 \\
\hline
\end{tabular}

3.2.6. H7 - Simplifying and Speeding up the Procedure (Including Permits) of Introduction of RES Technologies and Ensuring Public Benefit from RES Projects

A broader use of renewable energy technologies for energy production facilitates progress towards climate goals. Although activity direction $\mathrm{H} 7$ contains no mandatory policy activities and much of emphasis is put on hugs type of policy instruments policy goals related to making RES deployment easier do not conflict with climate goals and work in synergy with other policies, which stimulate progress towards achieving climate goals. Table 9 provides assessment of policies according to the CPI framework presented in Table 1.

TABle 9. Simplifying AND SPEEding UP THE PROCEDURE (INCLUding PERMITS) OF INTRODUCTION OF RES TECHNOLOGIES AND ENSURING PUBLIC BENEFIT FROM RES PROJECTS

\begin{tabular}{|c|c|c|c|c|}
\hline $\mathrm{C}^{\text {Criterion }}$ & $\begin{array}{l}\text { Neutral } \\
\text { interaction }\end{array}$ & $\begin{array}{l}\text { Synergetic } \\
\text { interaction }\end{array}$ & $\begin{array}{l}\text { Clarity of } \\
\text { interaction }\end{array}$ & $\begin{array}{l}\text { Conflict with other } \\
\text { policies }\end{array}$ \\
\hline Factor & 1 & 2 & 3 & 4 \\
\hline Political commitment (A) & 1 & 0 & 0 & 0 \\
\hline Functional overlap (B) & 0 & 1 & 0 & 0 \\
\hline
\end{tabular}




\begin{tabular}{lllll} 
Policy instruments (C) & 0 & 1 & 0 & 0 \\
Weight (D) & 0 & 1 & 0 & 0 \\
Time perspective (E) & NA & 1 & 1 & 0 \\
Cost of GHG reduction (F) & 0 & 1 & 0 & 0 \\
\hline
\end{tabular}

\subsubsection{H8 - Facilitating Acquisition of Financing for Stimulating Use of RES and Energy Efficiency}

Creation of a fund for financing activities aimed at facilitation of use of renewables and improvement of energy efficiency implies increase of financing available for deploying renewables and improving energy efficiency. Although this activity (policy instrument) is not of mandatory character it is still a carrot type of policy instrument with tentatively indirect positive impact on GHG emission reduction through broader diffusion of renewables and implementation of energy efficiency measures. Table 10 provides assessment of policies according to the CPI framework presented in Table 1.

\section{TABle 10. FACILITATING ACQUisition OF FINANCING FOR STIMULATING USE OF RES AND ENERGY EFFICIENCY}

\begin{tabular}{|c|c|c|c|c|}
\hline Criterion & $\begin{array}{l}\text { Neutral } \\
\text { interaction } \\
1\end{array}$ & $\begin{array}{l}\text { Synergetic } \\
\text { interaction } \\
2\end{array}$ & $\begin{array}{l}\text { Clarity of } \\
\text { interaction } \\
3\end{array}$ & $\begin{array}{l}\text { Conflict with other } \\
\text { policies } \\
4\end{array}$ \\
\hline Political commitment (A) & 0 & 1 & 0 & 0 \\
\hline Functional overlap (B) & 0 & 1 & 0 & 0 \\
\hline Policy instruments (C) & 0 & 1 & 0 & 0 \\
\hline Weight (D) & 0 & 1 & 0 & 0 \\
\hline Time perspective (E) & NA & 1 & 1 & 0 \\
\hline Cost of GHG reduction $(\mathrm{F})$ & 0 & 1 & 0 & 0 \\
\hline
\end{tabular}

\subsubsection{H9-Evaluating Possibility to Introduce Trading of Energy Savings}

Possibility to introduce mutual trading with energy efficiency savings where one user of the system can transfer the excess of own achieved savings to another user of the system does two things simultaneously: it both facilitates GHG reduction and creates a risk that the possibility to acquire/obtain / purchase excess energy efficiency savings for the sake of improving ones balance is used to avoid setting GHG reduction targets or setting less ambitious targets than it would be possible to set and achieve. Table 11 provides assessment of policies according to the CPI framework presented in Table 1.

In relation to the clarity of interaction criterion in case of factors $\mathrm{B}$ and $\mathrm{C}$ the indicator has been marked with ' 1 ' based on a potential risk that $\mathrm{H} 9$ policy measures can potentially demotivate investment in energy efficiency.

Table 11. Evaluating Possibility to Introduce Trading OF ENERgy SavingS

\begin{tabular}{|c|c|c|c|c|}
\hline Criterion & $\begin{array}{l}\text { Neutral } \\
\text { interaction }\end{array}$ & $\begin{array}{l}\text { Synergetic } \\
\text { interaction }\end{array}$ & $\begin{array}{l}\text { Clarity of } \\
\text { interaction }\end{array}$ & $\begin{array}{l}\text { Conflict with other } \\
\text { policies }\end{array}$ \\
\hline Factor & (2) & (2) & 3 & 4 \\
\hline Political commitment (A) & 0 & 1 & 0 & 0 \\
\hline Functional overlap (B) & 0 & 1 & 1 & 0 \\
\hline Policy instruments (C) & 0 & 1 & 1 & 0 \\
\hline
\end{tabular}




\begin{tabular}{|c|c|c|c|c|}
\hline Weight (D) & 0 & 1 & 0 & 0 \\
\hline Time perspective (E) & NA & 1 & 1 & 0 \\
\hline Cost of GHG reduction $(\mathrm{F})$ & 0 & 1 & 0 & 0 \\
\hline
\end{tabular}

3.2.9. H10 - Carrying out Research about Availability of RES for Energy Production (Except for Wind Energy) in Latvia's Territorial Waters, Including Evaluation of Possibility of Building New Infrastructure

Goals of this activity direction do not have an immediate and direct positive impact on achieving climate goals, however, in longer term, given the results of research showing that development of territorial and geothermal water for energy production is possible, impact on climate goals is forecast to be positive. Whether biogas as energy product is the best solution for achieving climate goals in longer term needs to be assessed separately. In short and medium-term there is potential to use biogas as a replacement to environmentally unfriendly fossil fuels (diesel, petrol) in transport sector. Indicator ' 1 ' has been marked for the factor and criterion $\mathrm{C} 1$ as $\mathrm{H} 10$ policy measures do not reduce $\mathrm{CO}_{2}$ emissions directly but can have long-term indirect positive contribution to $\mathrm{CO}_{2}$ reduction. Table 12 provides assessment of policies according to the CPI framework presented in Table 1.

TABLE 12. CARRYING OUT RESEARCH ABOUT AVAILABILITY OF RES FOR ENERGY PRODUCTION (EXCEPT FOR WIND ENERGY) IN LATVIA'S TERRITORIAL WATERS, INCLUDING EVALUATION OF POSSIBILITY OF BUILDING NEW INFRASTRUCTURE

\begin{tabular}{lllll}
\hline & Criterion & $\begin{array}{l}\text { Neutral } \\
\text { interaction }\end{array}$ & $\begin{array}{l}\text { Synergetic } \\
\text { interaction }\end{array}$ & $\begin{array}{l}\text { Clarity of } \\
\text { interaction } \\
\text { Factor }\end{array}$ \\
\hline Political commitment (A) & 1 & 2 & 3 & $\begin{array}{l}\text { Conflict with other } \\
\text { policies } \\
4\end{array}$ \\
Functional overlap (B) & 0 & 0 & 0 & 0 \\
Policy instruments (C) & 1 & 1 & 1 & 0 \\
Weight (D) & 0 & 1 & 0 & 0 \\
Time perspective (E) & NA & 1 & 0 & 0 \\
Cost of GHG reduction (F) & 1 & 1 & 0 & 0 \\
\hline
\end{tabular}

\subsubsection{H11 - Expanding the Work of Energy and Climate Council}

Activity direction $\mathrm{H} 11$ does not have an immediate and direct positive impact on reaching climate targets, however, creating and strengthening the source of expertise - energy and climate analysis group - can have positive impact on policy monitoring and review. The fact that there is an intention to develop cross-sectoral sustainable mobility sub-council to the Energy and Climate Council with the aim to strengthen cooperation with NGOs with expertise in their respective sector is a positive factor contributing to achieving climate goals. Table 13 provides assessment of policies according to the CPI framework presented in Table 1.

TABLE 13. EXPANDING THE WORK OF ENERGY AND CLIMATE COUNCIL

\begin{tabular}{|c|c|c|c|c|}
\hline Criterion & $\begin{array}{l}\text { Neutral } \\
\text { interaction } \\
1\end{array}$ & $\begin{array}{l}\text { Synergetic } \\
\text { interaction } \\
2\end{array}$ & $\begin{array}{l}\text { Clarity of } \\
\text { interaction } \\
3\end{array}$ & $\begin{array}{l}\text { Conflict with other } \\
\text { policies } \\
4\end{array}$ \\
\hline Political commitment (A) & 1 & 1 & 0 & 0 \\
\hline Functional overlap (B) & 0 & 1 & 0 & 0 \\
\hline
\end{tabular}




\begin{tabular}{lllll} 
Policy instruments (C) & 0 & 1 & 0 & 0 \\
Weight (D) & 1 & 0 & 1 & 0 \\
Time perspective (E) & NA & 1 & 1 & 0 \\
Cost of GHG reduction (F) & NA & NA & NA & NA \\
\hline
\end{tabular}

\subsubsection{H12 - Introducing and Applying Social Conditions Aspect in Energy and Climate Policy}

Activity direction $\mathrm{H} 12$ defines the need to foresee a mechanism of compensation for situations if transition to cleaner and more sustainable production in energy sector would create additional costs with energy poverty risks. Introduction of such policy measures potentially conflicts with climate policy goals by, for example, creating risk that in a situation when sustainable energy production contradicts the promise of cheap energy a political decision can be adopted to [artificially] maintain low energy prices, thus disincentivising energy users' motivation to invest in energy efficiency and rid the use of those energy resources, which contradict the interests of achieving climate goals. Table 14 provides assessment of policies according to the CPI framework presented in Table 1.

TABLE 14. INTRODUCING AND APPLying SOCIAL CONDITIONS ASPECT IN ENERGY AND Climate POLICY

\begin{tabular}{|c|c|c|c|c|}
\hline $7^{\text {Criterion }}$ & $\begin{array}{l}\text { Neutral } \\
\text { interaction }\end{array}$ & $\begin{array}{l}\text { Synergetic } \\
\text { interaction }\end{array}$ & $\begin{array}{l}\text { Clarity of } \\
\text { interaction }\end{array}$ & $\begin{array}{l}\text { Conflict with other } \\
\text { policies }\end{array}$ \\
\hline Factor & 1 & 2 & 3 & 4 \\
\hline Political commitment (A) & 0 & 0 & 1 & 0 \\
\hline Functional overlap (B) & 0 & 0 & 1 & 1 \\
\hline Policy instruments (C) & 0 & 0 & 1 & 1 \\
\hline Weight (D) & 0 & 0 & 1 & 1 \\
\hline Time perspective (E) & NA & 0 & 1 & 1 \\
\hline Cost of GHG reduction $(\mathrm{F})$ & 1 & 0 & 0 & 1 \\
\hline
\end{tabular}

\subsubsection{H13 - Elaborating Solution for the Number of Parallel Connections of Energy Supply} Systems

A research per se about optimisation of energy [supply] system through assessing possibility for the municipalities to determine/set conditions allowing to connect parallel energy supply systems to one object in one territory cannot create a direct and positive impact on reaching climate goals, but in theory there is potential that a regulatory framework, which supports energy system with parallel connection of energy supply system, can have positive impact on the use of RES in energy supply. However, parallel systems may imply extra costs and thus be contrary to the principle of installing and utilising the capacity of a single energy supply system with optimal costs. Table 15 provides assessment of policies according to the CPI framework presented in Table 1. 
TABle 15. ElABORATING SOLUTION FOR THE NuMBER OF PARALLEL CONNECTIONS OF ENERGY SUPPLY SYSTEMS

\begin{tabular}{lllll}
\hline & $\begin{array}{l}\text { Neutral } \\
\text { interaction } \\
\text { Factor }\end{array}$ & $\begin{array}{l}\text { Synergetic } \\
\text { interaction } \\
2\end{array}$ & $\begin{array}{l}\text { Clarity of } \\
\text { interaction } \\
3\end{array}$ & $\begin{array}{l}\text { Conflict with other } \\
\text { policies } \\
4\end{array}$ \\
\hline Political commitment (A) & 0 & 0 & 0 & 0 \\
Functional overlap (B) & 0 & 0 & 1 & 0 \\
Policy instruments (C) & 0 & 0 & 1 & 0 \\
Weight (D) & 0 & 0 & 1 & 0 \\
Time perspective (E) & NA & 1 & 0 & 0 \\
Cost of GHG reduction (F) & 1 & 0 & 0 & 1 \\
\hline
\end{tabular}

\subsubsection{H14 - Elaborating Research Programmes to Stimulate Research on Reaching Energy} and Climate Goals

Research serves as basis for analytical information which helps decision makers to formulate and implement evidence-based decisions and policy making. Policy measures of the activity direction $\mathrm{H} 14$ will supply decision makers with energy and climate policy analysis allowing to adopt decisions about maintaining, reviewing or terminating existing policies, or introducing new policies. Such an approach is synergetic with climate policy goals and is directed towards establishing / developing long-term sustainable policy and increases possibility that climate policy goals / targets could be granted a higher priority in comparison with other policies. Table 16 provides assessment of policies according to the CPI framework presented in Table 1.

TABle 16. Elaborating Research Programmes to Stimulate ReSEARCH ON REACHING ENERGY AND CLIMATE GOALS

\begin{tabular}{|c|c|c|c|c|}
\hline $7^{\text {Criterion }}$ & $\begin{array}{l}\text { Neutral } \\
\text { interaction } \\
1\end{array}$ & $\begin{array}{l}\text { Synergetic } \\
\text { interaction } \\
2\end{array}$ & $\begin{array}{l}\text { Clarity of } \\
\text { interaction } \\
3\end{array}$ & $\begin{array}{l}\text { Conflict with other } \\
\text { policies } \\
4\end{array}$ \\
\hline Political commitment (A) & 0 & 1 & 0 & 0 \\
\hline Functional overlap (B) & 0 & 1 & 0 & 0 \\
\hline Policy instruments (C) & 0 & 1 & 0 & 0 \\
\hline Weight (D) & 0 & 0 & 1 & 0 \\
\hline Time perspective (E) & NA & 1 & 1 & 0 \\
\hline Cost of GHG reduction $(\mathrm{F})$ & 0 & 1 & 1 & 0 \\
\hline
\end{tabular}

Altogether there are seven markers indicating an issue under criterion 4 (Conflict with other policies) and 36 markers indicating an issue with criterion 3 (Clarity of interaction). Five out of seven conflicting situations occur in one single direction of activity H12 (Introducing and applying social conditions aspect in energy and climate policy) while H5 (Facilitating production and use of biogas and biomethane) and H13 (Elaborating solution for the number of parallel connections of energy supply systems) have one marker each. As for the Clarity of interaction criterion markers are scattered among all directions of activity with no single direction without at least one indication of potentially contradictive policy formulation. 


\section{DiscuSsion AND CONCLUSIONS}

In terms of hugs, carrots and sticks approach, 44 out of 255 activities in the NECP2030 belong to the group of horizontal policies and policy instruments. Of those 36 can be identified as hugs, eight as carrots, and 17 as sticks. This illustrates the proportion of socalled soft measures in the overall portfolio of policy measures. A half of all directions of activity (policy directions) have no sticks in the policy portfolio and rely heavily on soft measures, like providing information, incentives, different other positive stimuli.

In terms of Climate Policy Integration approach, out of 14 horizontal policy areas (direction of activity) of the NECP2030 most can be identified as contributing to the progress towards climate goals. There are, however, several policies (for example, H1, H5, H9, H12, H13 and H14) that qualify as partially contributing. H12 (Introducing and applying social conditions aspect in energy and climate policy) and to a lesser extent also H5 (Facilitating production and use of biogas and biomethane) and H13 (Elaborating solution for the number of parallel connections of energy supply systems) qualify as ambiguous with risks of no sufficient contribution to reaching climate goals because of competing or conflicting interests between policies. Applying Climate Policy Integration approach to policy planning can save time and energy (also literally) allowing to avoid situations of confrontation between sectoral policies and climate policy goals. There is no universal consensus about whether CPI shall take place through vertical or horizontal approach as political systems vary and ability to exercise strong vertical control over climate policy planning and implementation may be strong in centralised political systems while strong awareness and presence of climate policy goals among policy actors across sectors may suggest applying horizontal CPI approach.

The way the horizontal policies are formulated leads to conclusion that policies have been included in the group of horizontal policies according to the principle of surplus, perhaps because it has been difficult to include these policies and policy instruments in other activity directions of the NECP2030. From the assessment of separate policies, it can be concluded that 1) micro-level assessment does not identify impacts / influences - the set policy instrument has no direct impact on climate policy and serves only as a precondition for the implementation of other policies; and 2) macro-level assessment, using such an approach, allows comparing and assessing interaction of policies, but in that case, there is insufficient detail to assess potential policy impacts on micro-level.

For the purpose of improving the next iteration of the National Energy and Climate Plan 2030 it is recommended that policy makers introduce a more comprehensive approach of systematising policies and policy instruments through the prism of overall national climate goals. Inclusion of policies and policy instruments in the group of horizontal policies would have stronger added value if they would be grouped with the aim of ensuring that different sectors of economy, when planning development, take into consideration climate aspects and avoid formulating their goals and policies in a way, which competes or even contradicts climate goals, and stating that horizontal policies have priority over policies of other policy directions in the NECP2030 and they serve as element uniting different policies.

\section{ACKNOWLEDGEMENT}

This research is funded by the Ministry of Economics of the Republic of Latvia, project "Energy and climate modelling towards net zero emissions", project No. VPP-EM-2018/NEKP_0001. 


\section{REFERENCES}

[1] European Commission. Communication From The Commission To The European Parliament, The European Council, The Council, The European Economic And Social Committee And The Committee Of The Regions. The European Green Deal. Brussels: European Commission, 2019.

[2] Electrification Alliance. Fit for 55\% Package: joint position [Online]. Accessed 4.10.2021]. Available: https://www.eurelectric.org/ff-55

[3] Aboltins R., Blumberga D. Key Factors for Successful Implementation of Energy Efficiency Policy Instruments: A Theoretical Study and the Case of Latvia. Environ. Clim. Technol. 2019:23:187-206. https://doi.org/10.2478/rtuect2019-0063

[4] Kettner C., Kletzan-Slamanig D. Is there climate policy integration in European Union energy efficiency and renewable energy policies? Yes, no, maybe. Environ. Policy Gov. 2020:30:141-150. https://doi.org/10.1002/eet.1880

[5] Kettner C., Kletzan-Slamanig D. Climate policy integration on the national and regional level: A case study for Austria and styria. Int. J. Energy Econ. Policy 2018:8:259-269.

[6] Jacob K., Kannen H. Integrated Strategies for Climate Policy Integration and Coherence: the Case of Germany. Berlin: Freie Universität Berlin, 2015.

[7] European Commission. National energy and climate plans (NECPs) [Online]. [Accessed 4.10.2021]. Available: https://ec.europa.eu/energy/topics/energy-strategy/national-energy-climate-plans_en

[8] Tagliapietra S., et al. The European union energy transition: Key priorities for the next five years. Energy Policy 2019:132:950-954. https://doi.org/10.1016/j.enpol.2019.06.060

[9] CEE Bankwatch Network. MAKING THE GRADE? A review of eight national energy and climate plans in central and eastern Europe. Prague: CEE Bankwatch, 2019.

[10] Cabinet of Ministers Republic of Latvia. Par Latvijas pielāgošanās klimata pārmaiṇām plānu laika posmam līdz 2030. Gadam (On Latvia's adaptation to climate change plan for the period until 2030.). Latvijas Vestnesis 2019:148. (in Latvian)

[11] United Nations. The Paris Agreement | UNFCCC [Online]. [Accessed 22.03.2021]. Available: https://unfccc.int/process-and-meetings/the-paris-agreement/the-paris-agreement

[12] European Union. Regulation (EU) 2018/1999 of the European Parliament and of the Council of 11 December 2018 on the Governance of the Energy Union and Climate Action, amending Regulations (EC) No 663/2009 and (EC) No $715 / 2009$ of the European Parliament and of the Council, Directives 94/22/EC, 98/70/EC, 2009/31/EC, 2009/73/EC, 2010/31/EU, 2012/27/EU and 2013/30/EU of the European Parliament and of the Council, Council Directives 2009/119/EC and (EU) 2015/652 and repealing Regulation (EU) No 525/2013 of the European Parliament and of the Council. Official Journal of the European Union 2018:L 328/1.

[13] Ministry of Environmental Protection and Regional Development Republic of Latvia. Latvijas stratēgija klimatneitralitātes sasniegšanai līdz 2050.gadam (Latvia's strategy for achieving climate neutrality by 2050.). Riga: VARAM, 2020. (in Latvian)

[14] Cabinet of Ministers Republic of Latvia. Latvijas Nacionālais enerǵētikas un klimata plāns 2021.-2030. Gadam (On the Latvian National Energy and Climate Plan 2021-2030. Year.). Latvijas Vestnesis 2020:29. (in Latvian)

[15] Boulding K.E. Three Faces of Power. CA: Sage, Newbury Park, 1990.

[16] Katre A., Tozzi A. Using hugs, carrots and sticks: How agents exercise power in the transition to community-owned energy systems in remote India. Energy Res. Soc. Sci. 2019:54:2019:129-139.

https://doi.org/10.1016/j.erss.2019.04.008

[17] Marmefelt T. Human knowledge, rules, and the spontaneous evolution of society in the social thought of Darwin, Hayek, and Boulding. J. Econ. Behav. Organ. 2009:71:62-74. https://doi.org/10.1016/j.jebo.2009.02.013

[18] Kesting S. Boulding's welfare approach of communicative deliberation. Ecol. Econ. 2010:69(5):973-977. https://doi.org/10.1016/j.ecolecon.2009.12.010

[19] Beilock R. The impact of caring on exchange choices and efficiencies: a modification of Boulding's three social organizers. J. Socio. Econ. 2000:29(3):263-279. https://doi.org/10.1016/S1053-5357(00)00072-X

[20] Mahmoodi J., et al. Combining "carrot and stick" to incentivize sustainability in households. Energy Policy 2018:123:31-40. https://doi.org/10.1016/j.enpol.2018.08.037

[21] Rintamäki H., Rikkonen P., Tapio. P. Carrot or stick: Impacts of alternative climate and energy policy scenarios on agriculture. Futures 2016:83:64-74. https://doi.org/10.1016/j.futures.2016.03.004

[22] Van Den Bergh J. C. J. M., Ferrer-I-Carbonell A., Munda G. Alternative models of individual behaviour and implications for environmental policy. Ecol. Econ. 2000:32:43-61. https://doi.org/10.1016/S0921-8009(99)00088-9

[23] United Nations. United Nations Conference on Environment \& Development. New York: UN, 1992.

[24] Adelle J., et al. Climate Change and Energy Security in Europe: Policy Integration and its Limits. Stockholm: Sieps, 2009:4

[25] Jordan A., Lenschow A. Policy paper environmental policy integration: A state of the art review. Environ. Policy Gov. 2010:20(3):147-158. https://doi.org/10.1002/eet.539

[26] Kivimaa P., Mickwitz P. Making the Climate Count. Climate Policy Integration and Coherence in Finland. Helsinki: Finnish Environment Institute, 2009. 
[27] Lafferty W., Hovden E., Lafferty W. M. Environmental policy integration: towards an analytical framework Environmental Policy Integration: Towards an Analytical Framework. Env. Polit. 2010:12(3):1-22. https://doi.org/10.1080/09644010412331308254

[28] Dupont S., Oberthür C. Insufficient Climate Policy Integration in EU Energy Policy: the importance of the long-term perspective. J. Cont. Europ. Res. 2012:8(2):1-24.

[29] Dupont C. Climate Policy Integration in the EU. The Economic, Social and Political Elements of Climate Change. Climate Change Management. Springer, 2011:385-404. https://doi.org/10.1007/978-3-642-14776-0 25

[30] Runhaar H., Driessen P., Uittenbroek C. Towards a Systematic Framework for the Analysis of Environmental Policy Integration. Environ. Policy Gov. 2014:24:233-246. https://doi.org/10.1002/eet.1647

[31] Mickwitz D., et al. Climate Policy Integration, Coherence and Governance. PEER, 2009.

[32] European Commission. Europe 2020, 2010. https://ec.europa.eu/eu2020/pdf/COMPLET EN BARROSO 007 Europe 2020 - EN version.pdf (accessed September 18, 2020) 